\title{
Safeguarding the atom: the nuclear enthusiasm of Muriel Howorth
}

\author{
PAIGE JOHNSON*
}

\begin{abstract}
There was more than one response to the nuclear age. Countering well-documented attitudes of protest and pessimism, Muriel Howorth (1886-1971) models a less examined strain of atomic enthusiasm in British nuclear culture. Believing that the same power within the atomic bomb could be harnessed to make the world a 'smiling garden of Eden', she utilized traditionally feminine domains of kitchen and garden in her efforts to educate the public about the potential of the atom and to 'safeguard' it on their behalf. Boldly entering an overtly masculine arena in which, as a woman and a layperson, she was doubly an 'other', Howorth used a variety of publications, organizations and staged events to interpret atomic science and specifically to address women. Her efforts, dating roughly from 1948 to 1962, preceded but had broad overlaps with official Atoms for Peace programmes, and culminated in the formation of the Atomic Gardening Society in 1960 to promote the cultivation of gamma-irradiated seeds by British gardeners.
\end{abstract}

Muriel Howorth is the subject of slight mentions in a few journal articles and even fewer books, largely due to her collaboration with 1921 Nobel laureate Frederick Soddy, for whom she wrote a first, fawning, biography. ${ }^{1}$ Her own life, a great deal of which was spent in atomic advocacy, has remained largely unexplored. A sort of delicacy is required in doing so. It is easy to laugh at, even to dismiss, someone who carried an irradiated potato in her pocket, ${ }^{2}$ who presented models of the atom to local dignitaries, ${ }^{3}$ who

* University of Tulsa, Keplinger Hall M226, 800 South Tucker Drive, Tulsa, Oklahoma 74104, USA. Email: paige-johnson@utulsa.edu.

Muriel Howorth's grandchildren-Julia, David and John, and granddaughter-in-law Sue-generously opened the family home, their personal memories and 'Mitzi's' mementos to me. Fellow historian Valerie Joynt drove me all the way from Hampshire to Eastbourne to find Muriel's home and two atomic garden sites, including Wannock Gardens where Jenny Wootton shared remembrances of her father's atomic gardening. Samantha Hide of the Eastbourne Library searched out important local publicity surrounding Muriel's atomic efforts. The University of Tulsa librarians patiently answered many requests for obscure atomic publications, research assistant Kate Nelson helped me sort and transcribe them, and the University of Tulsa Office of Research supported my attendance at the 2010 conference on British Nuclear Culture at the University of Liverpool to present the genesis of this paper. All were essential to the writing of this article, and have my sincere gratitude.

1 Howorth's relationship with Soddy is the only aspect of her life detailed in secondary sources, and is thoroughly covered in the modern biography of Soddy by Linda Merricks, The World Made New: Frederick Soddy, Science, Politics, and Environment, New York: Oxford University Press, 1996. Howorth's unusual atomic activism was first published by Sophie Forgan, and appears in her work on the representations of atomic science in Britain between 1945 and 1960. Sophie Forgan, 'Atoms in wonderland', History and Technology (2003) 19, pp. 177-196.

2 Austin Hatton, 'Atomic vegetables investigated', Saskatoon Star-Phoenix, 27 October 1959.

3 A photograph of Muriel Howorth, wearing a fantastic hat and presenting a model of the lithium atom to the mayor of Eastbourne, is among her personal papers. The mayor appears befuddled by the gift. 
staged isotopic pantomimes ${ }^{4}$ and served mutated peanuts at a dinner party. ${ }^{5}$ While it is now acceptable, and even admirable, that in spite of being both a woman and a nonscientist Howorth wrote her own entry in the Who's Who of Atoms, ${ }^{6}$ the greater otherness that she exhibits is that of having been on the wrong side of history as it is now translated. A conscious attempt has been made to adjust this distortive lens by setting Howorth within her own time, with the awareness that had her energetic civic engagement been in protest to, rather than in praise of, all things nuclear she might now be viewed very differently. ${ }^{7}$

This first attempt to excavate Muriel Howorth's story necessarily has more of biography than of historiography, ${ }^{8}$ and is admittedly incomplete in this space. Nevertheless, it illuminates pertinent issues within the study of British nuclear culture: the popularization of atomic science, the relationships of non-expert and women 'others' with atomic science and scientists, the efforts of government agencies to direct public opinion about nuclear matters, and the nature of atomic enthusiasm as expressed by a woman who fashioned her own nuclear identity and used it to promote not just 'atoms for peace' but herself.

\section{The interpretation of radium}

Muriel Howorth was living in Eastbourne, having been employed during the Second World War with the Ministry of Information and the Royal Aircraft Establishment at Farnborough, when a letter came 'out of the blue' in 1948 inquiring 'if I would like to interest myself in atomic energy'. ${ }^{9}$ Admittedly having no previous knowledge of the subject, Howorth consulted the technical library of the Ministry of Supply, where she encountered a thrice-reprinted work by Frederick Soddy entitled The Interpretation of Radium. 'By the time I had reached page 183 I was a firm believer in the power of the

Howorth's personal papers are uncatalogued. They will be referred to in these endnotes as the Wilkinson Collection, as they are now in the possession of her grandchildren.

4 Muriel Howorth, Isotopia: An Exposition on Atomic Structure... Written in the Form of a Mime to be Produced by Fourteen Players, Eastbourne, 1949. The pantomime Isotopia was never formally published; the typewritten, hand-bound copy in the British Library is the only one known to exist. It details the fourteen players; their spangled, silver and parachute-cloth costumes; and their dance steps as they illustrated the forward march of atomic knowledge from Democritus to the Geiger counter.

5 This account of the dinner at which irradiated peanuts were served is found in Muriel Howorth, Atomic Gardening, Eastbourne: New World Publications: Distributed in the USA by Rogers Book Service, 1960, p. 14.

6 Among the Wilkinson Collection are two typewritten atomic 'résumés' of her activities, dated 1962 and 1964. Who's Who in Atoms was published by Harrap Research Publications, London. Muriel Howorth appears in the 1969 volume.

7 For the concept of the other in popular science see Bernadette Bensaude-Vincent, 'A historical perspective on science and its "Others"', Isis (2009) 100, pp. 359-368.

8 For the role of biography in the history of science see Mary Terrall, 'Biography as cultural history of science', Isis (2006) 97, pp. 306-313.

9 Howorth's account of her receipt of the letter is contained in the Introductory to her biography of Soddy. Muriel Howorth, Introductory, in Howorth, Pioneer Research on the Atom: The Life Story of Frederick Soddy, London: New World Publications, 1958. 
atom for good.' On that page she had read, 'the nation which can transmute matter could transform a desert continent, thaw the frozen poles, and make the whole world one smiling Garden of Eden' ${ }^{10}$

Assertions that nuclear power could return mankind to an idyllic, prelapsarian bliss would become familiar after the Second World War, when a variety of governmental and scientific agencies sought to provide their own interpretation of radium (Figure 1). But Soddy was ahead of his time and of his fellow scientists in the early twentieth century, speaking into the public sphere when most spoke exclusively to their own academy. In addition to his well-documented prescience about the nature of nuclear power, Soddy was convinced of the necessity of public engagement with science in a way that prefigured the advocacy of atomic scientists after the Second World War, and that of his eventual acolyte Muriel Howorth. ${ }^{11}$ But when she first wrote to inform him of her atomic societies, his response was characteristically gruff: 'while I am entirely with you in approving the dissemination of knowledge to the laymen, I am poles apart from you in disapproving entirely as to the manner in which this is being done'. ${ }^{12}$

Howorth's 'manner' of activism, by the time she wrote to Soddy in 1952, followed a personal pattern that pre-dated her atomic involvement. Born Muriel Kathleen Edgar in Bishop Auckland, County Durham, in 1886, she was desirous at an early age of 'being useful in International Affairs', and following a diploma from the Royal Academy of Music and a stint at finishing school she began to find her way to do so, venturing first into the world of film, which, like atomic energy some twenty years later, was dominated by men. It does not diminish Muriel Howorth née Edgar's intelligence or inventiveness (she patented an early picture/sound recording device called the Talkiefone) to say that the talent most evident in her ventures was a charismatic leadership. She displayed a unique ability to gather people around her and to make them believe not only in her cause, but in Howorth herself. Invariably, Howorth listed herself as 'founder', 'director', 'president', 'ambassador' of the organizations she formed-titles and positions which she had invented but which her followers enthusiastically affirmed that she should retain. In the 1930s, Howorth garnered the support of an estimated seven hundred women for her Women's International Film Association to bring the influence of the 'thinking British public' to the film industry. ${ }^{13}$ Nascent in this early activism were themes of appealing to the intelligent layman and engaging women that would reappear in

10 Howorth, op. cit. (9).

11 Kirk Willis discusses Soddy's pre-war atomic writings and influence at length. Kirk Willis, 'The origins of British nuclear culture, 1895-1939', Journal of British Studies (1995) 34, pp. 59-89.

12 Merricks, op. cit. (1), p. 180.

13 Details of Howorth's pre-atomic activism are summarized from her autobiographical Ideas and Aspirations. Sheldon Wilkinson, Ideas and Aspirations, Eastbourne, 1937. She was born Muriel Edgar, and married Sheldon Wilkinson, a naval officer, in 1913. They divorced in 1929. She married Major Humphrey Howorth in 1937. She dropped the 'Mrs' and always used the name 'Sheldon Wilkinson' for her film-related activities, which are significant enough in their own right to deserve further study. In addition to her work with the Talkiefone and WIFA, she filmed in Turkey and Greece and produced a short film of the bishop of London. Howorth said she was working on another autobiography, which would have included her atomic activities, during the last years of her life. No trace of it has been found. 


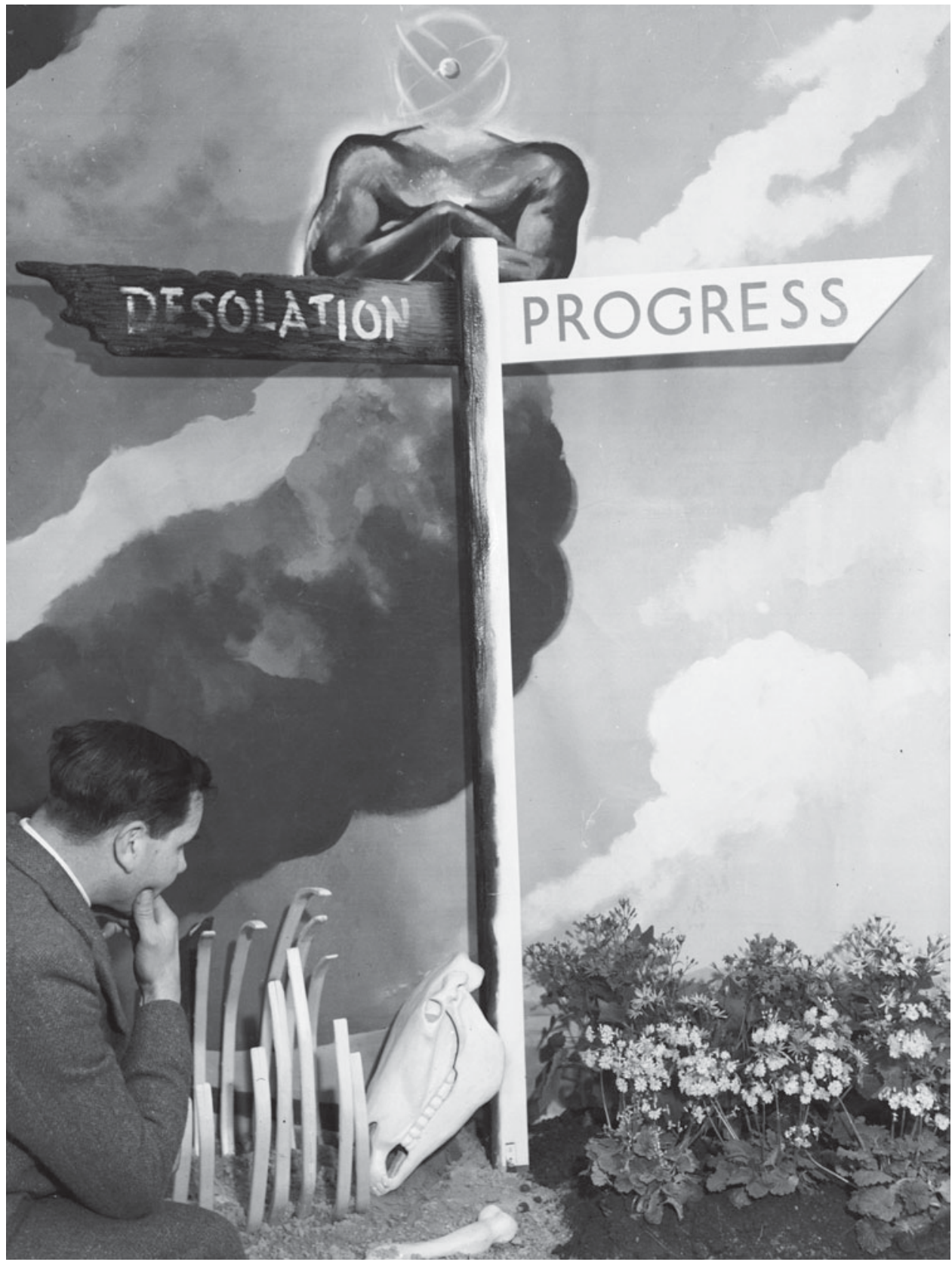

Figure 1. A flowering garden represents 'Progress' in an exhibition at Dorland Hall, London, depicting the two potential roads of atomic energy. The exhibition, part of the 'Atom Train', was the first to present atomic energy to the public and was sponsored by the British Atomic Scientists Association. Photograph credit: Reg Birkett/Keystone/Getty Images, 'A choice of future', 23 January 1947. 
Howorth's atomic societies, ${ }^{14}$ an emphasis on self-publication that presaged modern communication methods like blogging, and a developing modus operandi: form a society with an official-sounding name, find a patron, stage an event and work the press. $^{15}$

As a patron for atomic science, one could hardly do better than Albert Einstein. Like Soddy, Einstein was committed to the necessity of public engagement and he replied in the affirmative to Howorth's request for his patronage of her Institute of Atomic Information for the Layman (IAIL) in February of 1953: 'I am gladly willing to become patron of your organization but I cannot visit England for reasons of poor health.' 16

Though much has been made of the gulf between the scientist and the layman in this Cold War era, Howorth never seems to acknowledge what others have perceived as a chasm. ${ }^{17}$ Her fawning attitude toward scientists (Howorth's works are replete with references to their nobility and genius) did not inhibit her approach to them; she simply wrote to Einstein, as she had to Soddy, as she later would to Niels Bohr, ${ }^{18}$ telling them of her ventures and asking for their support. Having received a very traditional training in the arts, ${ }^{19}$ she moved smoothly and of her own volition into the sphere of science and technology; her advocacy for the layman even earned her a place at the 1953 and 1954 reunions of the Nobel laureates in Bavaria, to which she was personally invited by the conference organizer, Dr F.K. Hein. 'I would be ever so pleased', he wrote, 'if you would give us the pleasure to be present at our meeting, as our endeavourings are very much like yours'. Hein also featured a quote from Howorth at the top of the 1953 opening programme: 'What is discovered by the scientist today must be made known, and must be implemented by the layman, for the layman, by you and by me, because it is for you and for me'. ${ }^{20}$

Howorth attended the reunions at the side of Frederick Soddy, who ultimately yielded to the invitation to join her atomic efforts and until his death in 1956 was a perennial

14 Howorth formed at least two other societies for women: the Britannia League, c.1939, and the New Parthenon, c.1964. These were never organizations for the promotion of women's rights; rather they were forums that provided a venue for women (and particularly Howorth herself) to air their opinions in a setting of educative lectures. Limited materials from both societies are among the Wilkinson papers.

15 Howorth constructed all of her societies with a quite modern attention to what would now be called 'branding': generating slogans, logos and letterheads that gave the impression of a large organization; issuing press releases; self-publishing supporting documents; and attaching the organization to a reputable public figure.

16 Muriel Howorth was very proud of Einstein's response, and quoted it often. Actual copies of any correspondence between them have not been found: Howorth, op. cit. (9), p. 324. According to family history, she also met Einstein at one of the Nobel laureates' meetings she attended with Soddy.

17 See, for example, Bernadette Bensaude-Vincent, 'A genealogy of the increasing gap between science and the public', Public Understanding of Science (2001) 10, pp. 99-113.

18 Howorth's correspondence with Frederick Soddy is archived at the Bodleian Library, and well characterized by Merricks. Howorth's limited correspondence with Niels Bohr is preserved in his archives in Copenhagen: Niels Henrik David Bohr General Correspondence Box: Ho-Hv, OCLC\# 488870926.

19 According to a record of education in the Wilkinson Collection, Muriel attended Canon Francis Holland College in London and then the Royal Academy of Arts, becoming a licentiate and following her studies with finishing schools in France and Vienna.

20 A Layman, 'The Nobel prizewinner's conference in Lindau, Bavaria', Atomic Digest (1953), pp. 18-25. 
guest of honor at IAIL events. She staged a 'Radioactivity Jubilee' in November of 1953 to celebrate the anniversary of his accomplishments:

you owe to none of the national institutions, ostensibly concerned with pure science, that its [radioactivity's] Jubilee has not been completely ignored or forgotten but entirely to Muriel Howorth and her Institute of Atomic Information for the Laymen that this half-hour has been allotted to me to recall the event. ${ }^{21}$

Howorth fashioned her own interpretation of radium, communicating science to her lay members in ways that more mainstream organizations refused to support. The Royal Society curtly declined her invitation to send a representative to the Radioactivity Jubilee; she promptly reproduced their refusal in her Digest for all to scorn. ${ }^{22}$ There is no evidence that she experienced any hesitation, as a woman, in stepping into the maledominated field of the interpretation of science. She slipped easily between high and low scientific culture and encouraged others to as well, hesitating neither to direct the attention of her layman associates 'up' to mesons and wave mechanics, nor to bring the interpretation of science 'low' by allying it with theatre and even commercializing it; her final atomic endeavour was the promotion of gamma ray-irradiated seeds for purchase by British gardeners. ${ }^{23}$ Howorth was without prejudice as to what was appropriate, focused on doing whatever was effective to promote both the atom and herself.

\section{Atoms for women}

In October of 1950 Muriel Howorth staged an atomic occasion so eccentric as to be hardly believable had it not been recorded by the foreign desk at Time magazine. On the occasion of its second anniversary, the Atomic Energy Association of Great Britain staged Isotopia: An Exposition on Atomic Structure, Written in the Form of a Mime (author, Mrs Muriel Howorth) at the Aldwych Waldorf Hotel:

Before a select audience of 250 rapt ladies and a dozen faintly bored gentlemen, some 13 bosomy A.E. Associates in flowing evening gowns gyrated gracefully about a stage in earnest imitation of atomic forces at work. An ample electron in black lace wound her way around two matrons labeled 'proton' and 'neutron' while an elderly ginger-haired Geiger counter clicked out their radioactive effect on a pretty girl named Agriculture. At a climactic moment, a Mrs. Monica Davial raced across the stage in spirited representation of a rat eating radioactive cheese. Mrs. Davial, it was noted in the program, had 'recently returned from a trip to Tibet' and hence presumably had a nice understanding of these things. ${ }^{24}$

Even after such an evening, Howorth was dreaming of greater things, hoping for a repeat performance of Isotopia in the Royal Albert Hall. 'We would have room there', she

21 This quote of Soddy's was another favourite of Howorth's. She gave it a prominent place in a small pamphlet of quotes by Soddy which she published on the occasion of his death, though it was hardly one of the most important pronouncements of a Nobel laureate.

22 'Royal Society to Major H. Howorth, 7 May 1953', Atomic Digest (1953), p. 26.

23 The methods by which Howorth obtained, reconfigured and communicated expert knowledge to her lay members are worthy of further study.

24 Anon., 'Foreign news: the explosion and all', Time, 30 October 1950, p. 40, available online at www. time.com/time/magazine/article/0,9171,805562,00.html. 
explained with a hectic smile to the Time reporter, 'for all the 92 transmutations of the atom. Then we could have the explosion and all'. ${ }^{25}$ At the end of the mime the Narrator made a final pitch while Atom Man (who was a woman) continued to dance about the stage:

This is the kind of information which the Atomic Energy Association disseminates at its meetings here in the Waldorf, and at the meetings of any organization which appeals for atomic information. The Ladies' Atomic Energy Club devised this Mime to make a visual presentation of the Peace-time uses of the atom... ${ }^{26}$

Howorth's societies, as well as her publications, can be moving targets. She adjusted names and adapted goals at will, leaving no record or reasons beyond the sudden appearance of a new letterhead, title or slogan. The Ladies' Atomic Energy Club was originally an auxiliary of the Atomic Energy Association - the first of her several atomic societies - which was the precursor to the Institute of Atomic Information for the Layman, which itself morphed into the new Institute for Atomic Information, all of which retained an adjunct organization exclusively for women, as evidenced by scattered references to the 'Ladies' Club'. Since these were not official societies, there are no official records, including of any membership rolls, and Howorth's personal papers have unfortunately contained no specifics of these unique early efforts to address women about the nature of atomic science. ${ }^{27}$

She did, however, produce a book specifically targeted at women, in keeping with the aim of the club 'to lead women out of the kitchen and into the atomic age', as well as an illustrated atomic volume for children (Figure 2). 'Not to know about atomic energy and the wonderful things it can do', she proclaimed, 'is like living in the Dark Ages' ${ }^{28}$ In the foreword to Howorth's self-published Atom and Eve (1955), her friend Lady Helen Nutting praised it as a work that 'any intelligent man or woman' can understand (emphasis added); a welcome change from the masculine 'layman' ubiquitous in most Cold War works of popular science. ${ }^{29}$ Howorth did certainly direct remarks to this intelligent and interested everyman, particularly when writing for her atomic societies, but also wrote specifically for everywoman. ${ }^{30}$ Atom and Eve was dedicated 'to all women everywhere', and subtitled Atoms for the Home, 'a simple story of the atom and

25 Anon., op. cit. (24).

26 Anon., op. cit. (24).

27 Muriel Howorth, Atom and Eve, London: New World Publications, 1955, p. 8. In the foreword to Atom and Eve, Howorth refers obliquely to some of her prior atomic activities, recording that she had spoken about the peaceful uses of the atom to 'many audiences in London' seven years prior, which would have been in 1948. She later states that 'a little while ago a women's organization asked me to write a thousand-word study essay on the Peacetime Uses of Atomic Energy' (p. 22), and 'as far back as 1948, having contacts from a year's stay in America, I wrote to the universities for information as to progress being made in atomic energy for peaceful purposes', and 'a paper I subsequently wrote on the subject' (p. 45).

28 Anon., op. cit. (24), p. 40.

29 See particularly Forgan, op. cit. (1), pp. 178-179. Forgan notes that the idea of the observant, intelligent layman was particularly strong in the British imagination in the period from 1945 to 1960 .

30 Howorth used the term 'layman' in a non-gendered fashion, including as a self-reference. See Howorth, op. cit. (27), p. 71. 


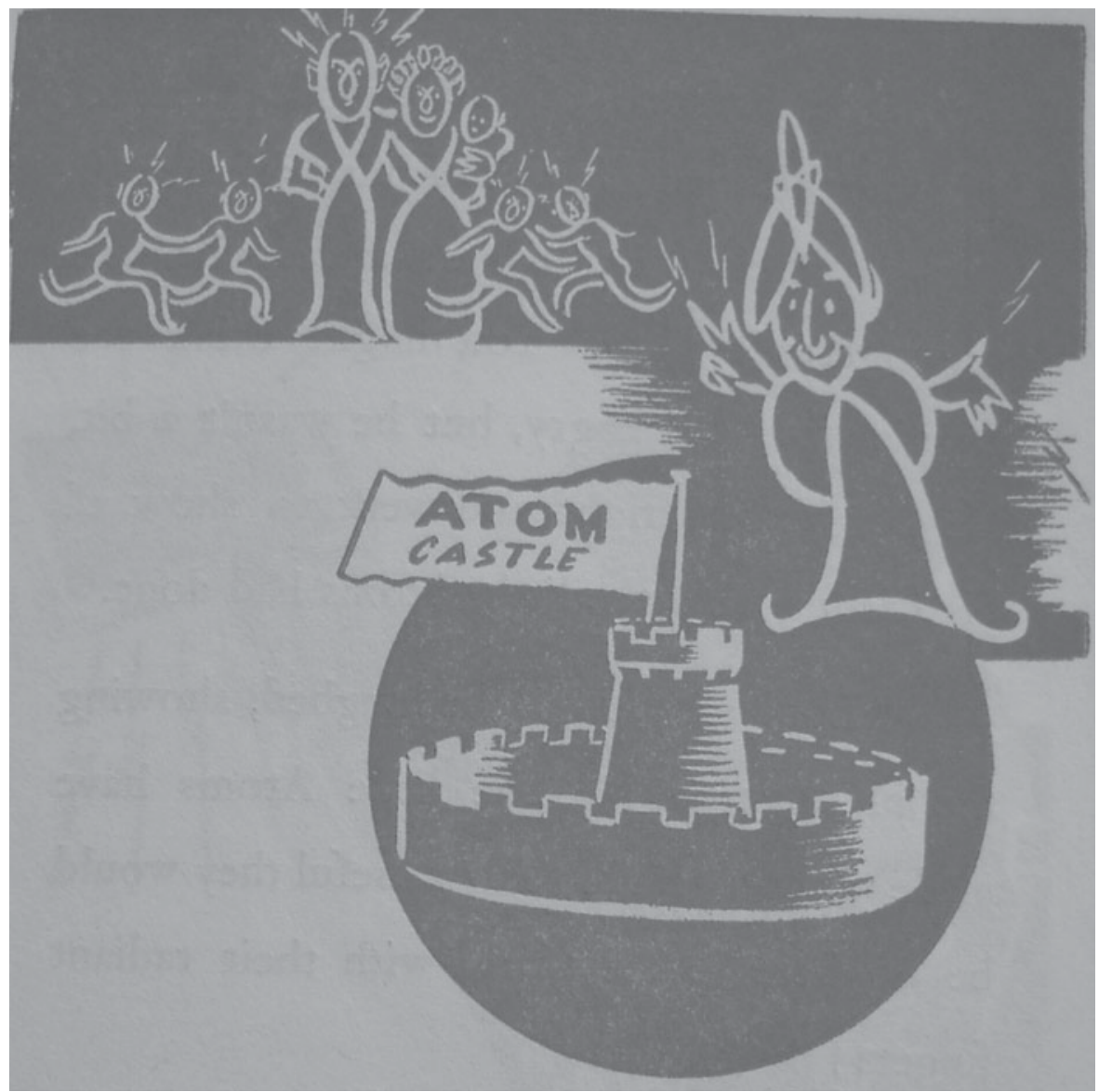

Figure 2. With the aim of reaching a new generation with the wonderful news of atomic science, Howorth published Atoms in Wonderland 'for the young and the not so young' sometime between 1950 and 1955. Every other page was a cheerful cartoon drawing featuring an anthropomorphized atom family of Daddy Proton, Mummie Neutron and their electron children, who lived happily in their atom castle and learned to serve the 'Biggie' humans. Like most of Howorth's works, it was self-published in a small print run. The only known copy is in the Women's Library of London Metropolitan University.

its uses, for home reading'. Like all of Howorth's publications, it promoted peaceful uses of atomic energy:

After the fall of the first atomic bomb many women hid their heads in the sand, so depriving themselves of any knowledge of the peaceful uses of atomic energy which were spreading, like a healing sun, over the ashes of destruction...I do not intend to enlarge on its destructive application. We have all heard enough of that, and indeed, I think this dismal reiteration of 'the bomb' has prevented many women from learning about the good which this energy locked up in the atom since time began is doing for the welfare of mankind today. ${ }^{31}$

31 Howorth, op. cit. (27), pp. 7-8. 
The slim volume also provided foundational instruction in the basic principles essential to understanding nuclear science such as atomic structure, the periodic table, and the nature of radiation. Howorth's slight condescension to her female audience - 'it was my idea to explain, in the simplest of words, some things about atomic energy' 32 - was better than that at the 1951 Festival of Britain applied to all members of the public: 'nor is science a strange and special kind of knowledge. Its underlying ideas are not difficult and not at all extraordinary. They can be understood and enjoyed by everyone'. ${ }^{33}$ Howorth's chapters on nuclear reactors, though simplistic, emphasized the ability of women to comprehend these matters:

I am trying to convey to you that atoms are cooked in the atomic oven much in the same way as you bake your cake... The atomic oven, as you see, has certainly unique methods of operating but to understand it is not beyond the power of the woman-at-home. ${ }^{34}$

Later she would credit her Ladies' Club attendees with an even greater capacity, announcing for their regular meeting a discussion led by a Mme Soubouttine on 'New Aspects of the Atom' to include indeterminacy, wave mechanics and mesons. ${ }^{35}$

The 'Atoms in the home' chapter of Atom and Eve included a discussion of the cold sterilization of food by gamma rays, with the news from America that 'potatoes irradiated two years ago are still fresh and not sprouting. I am trying to get some of these to taste'. ${ }^{36}$ By 1959 Howorth had done so, appearing in the newspapers for having cooked and consumed food preserved by irradiation. It was a traditional English meal of beef, vegetables and Yorkshire pudding - except that the potatoes and onions were three years old and completely tasteless, having been kept sterile in a storeroom at Harwell thanks to the inclusion of a few grains of radioactive sodium. Howorth asserted that it was alleviating hunger, not taste, which mattered. After staging the meal she sometimes carried an irradiated potato in her handbag or pocket - a symbol, she said, 'of the way eventually we are going to use nuclear energy to help in feeding the undernourished people of the world'. ${ }^{37}$ It is notable that although Howorth utilized the traditionally feminine loci of the kitchen, and later the garden, in her interpretations of atomic science, she refused to be confined to them. Over the course of her atomic activism she had much more to say about factories and hospitals, power plants and laboratories than about the home.

Asked to speak to 'The role of women in the atomic age' for a commencement address in 1947, former US congresswoman Clare Boothe Luce completely avoided the question, asserting that the specific challenges of the 'atomic age' had no bearing

32 Howorth, op. cit. (27), p. 7.

33 Forgan, op. cit. (1), p. 231. The emphasis of statements such as these is on the supposed simplicity of science rather than the presumed intelligence of the public.

34 Howorth, op. cit. (27), p. 35.

35 'Meetings in London', Atomic Digest (1954) 2, p. 31.

36 Howorth, op. cit. (27), p. 46.

37 Hatton, op. cit. (2). 
on the role of women as it always had been and would be. ${ }^{38}$ But Howorth was unafraid, asking directly, 'What is the place of women in the Atomic World?' and answering, 'The Atom for Peace is their business'. ${ }^{39}$ It would be as late as 1964, and the timelessly titled Intelligent Woman's Guide to Atomic Radiation by Margot Bennet, a former crime writer, before a popular atomic work would again address women so specifically. Beginning, as had Howorth, with the foundational scientific concepts necessary for understanding the atomic age, Bennet moved on to address the legitimate fears women felt about issues such as the effect of radioactive fallout on breast milk - fears that Howorth, for all her societies, books, and events, never acknowledged. 40

These fears, in particular that the cumulative effects of fallout from nuclear tests could lead to genetic abnormalities, were expressed by Dr Edith Summerskill, MP of the Labour opposition, when she entered the nuclear debate as a non-enthusiast in 1955, the same year that Muriel Howorth published Atom and Eve. Making an explicitly gendered argument that 'man has invented a lethal weapon the properties of which offer a threat to women's creative powers', she hoped that the 'instinctive aversion to fighting which prompts every normal woman may find world-wide expression' in opposition to nuclear testing. ${ }^{41}$ Muriel Howorth also entered with passion into what had been a male sphere - the interpretation of atomic science to the public - but took the view that the opportunities of the atomic age increased the potential for women's creative power, gave them a new field of endeavour in which to involve themselves, and would preserve their generations to come from famine and want. She hoped that women would 'shout the good news of the peaceful uses of atomic energy from the house tops and radiate the joie de viure which comes from a knowledge of the make-up of this magic world in which we live'. 42

Howorth's performance of Isotopia was reviewed again as part of a 1957 Life magazine article on English eccentrics. In a lightly mocking tone reminiscent of the Time article it recorded the details about Isotopia's sister composition, a piano concerto entitled Atomica by Lady Anderson. 'Atomica consisted chiefly of loud, heavy chords, which indicated atomic bombs, and springing, tinkling passages which reflected the extreme surprise and alarm of the human race'. ${ }^{43}$

It is even easier, now, to make fun of Howorth's events and publications than it was for the Time and Life reporters. But they took place in the context of nuclear protest plays and songs that commonly personified the atom, only with a demonic mien instead

38 Clare Booth Luce, 'The role of women in the atomic age', in Saint Mary's College Notre Dame, Commencement Address, 31 May 1947.

39 H. Howorth, 'Editorial', Atomic Digest (1955), p. 2. Though this editorial at the front of the Summer 1954 issue of Atomic Digest was signed H. Howorth, it was clearly the voice and ideas of M. Howorth.

40 Margot Bennet, The Intelligent Woman's Guide to Atomic Radiation, Harmondsworth: Penguin, 1964, pp. $105-120$.

41 House of Commons debates, Nuclear Explosions (Genetic Effects), 22 March 1955. Full text of the debate is available online at www.theyworkforyou.com/debates.

42 Howorth, op. cit. (27), p. 71.

43 Nigel Dennis, ‘A treasury of eccentrics', Life, 2 December 1957, p. 112. 
of the smiling face that Howorth saw. ${ }^{44}$ Howorth's own events can be seen as a response to these, in accordance with her desire to turn the societal conversation away from dismal reiterations of the bomb. Her 'Atom and Eve' vied with 'Atom and Evil' for cultural dominance:

This is the story of Atom and Evil

Their courtship is causin' a great upheaval

Now Atom was a sweet young innocent thing

Until the night that Miss Evil took him under her wing

Now Atom was an honest, hard workin' man

He wanted to help out the human clan

But Evil got him drunk on prejudice and hate

And she taught him how to gamble with Humanity's fate

(So true!)

I'm talkin' 'bout Atom, and Evil

Atom and Evil

If you don't break up that romance soon

We'll all fall down and go boom, boom, boom! ${ }^{45}$

\section{Safeguarding the atom}

Muriel Howorth's folly of a mime appeared three years, and her first atomic society five years, before President Dwight D. Eisenhower's famous 1955 'Atoms for peace' speech kicked off what John Krige has termed a 'polyvalent propaganda effort' to convince the worldwide public of the atom's benignity. ${ }^{46}$ If, as Krige has noted, 'Historians of science and technology have paid little or no attention to Atoms for Peace', ${ }^{47}$ the atomic organizations that preceded it have received even less notice. And yet they raise pertinent questions about the attempts of governments to influence public attitudes in the earliest years after the atomic bomb was detonated when it was most critical that nuclear fears be dispelled.

The Atomic Scientists Association (ASA), founded in 1946 with the goal of 'informing the British public on the potentialities and implications of atomic energy', ${ }^{48}$ displayed a greater symmetry in their early educative efforts than did Howorth, admitting the possible outcome of 'Desolation' as well as the 'Progress' that she hailed (Figure 1). Conceived as politically neutral, it has nonetheless been noted that

the difference between 'official' and 'unofficial' scientific thinking on political matters was not always clear... The ASA ... had an active membership inside the United Kingdom Atomic

44 The author is grateful to Ingrid Jendrzejewski for making me aware of atomic protest songs and dramas at the 2010 Conference on British Nuclear Culture at the University of Liverpool.

45 Golden Gate Quartet, Atom and Evil (1947), lyrics available at www.atomicplatters.com/more.php? id=115_0_1_0_M, 1947.

46 John Krige, 'Atoms for peace, scientific internationalism, and scientific intelligence', Osiris (2006) 21, pp. 161-181.

47 Krige, op. cit. (46), p. 165.

48 'Atomic science: an announcement', New Scientist, 20 December 1956, p. 5. 
Energy Authority and its roll of vice-presidents included one of the British government's most highly placed scientific advisors, Sir John Cockcroft the Director of the Atomic Energy Research Establishment at Harwell. ${ }^{49}$

This lack of clarity as to what was official and what was not extends to the atomic efforts of Muriel Howorth. She had been employed during the war by the Ministry of Information, and her only son, Dr David S. Wilkinson, recalled tours of Kent and Sussex in a car with dimmed headlights to show propaganda films to isolated garrisons but asserted emphatically that Howorth was not a spy, just a passionate polemicist. ${ }^{50}$ Howorth's own record of her employment shows a transfer to the Ministry of Supply in 1946. It is followed by a notation of '1948 Atomic Energy Department' and 'wrote booklets'.51

The nature of any financial commitment of the British government to Muriel Howorth and her atomic societies is unknown, but the extent of IAIL activities indicates that significant resources were required. Howorth hosted Institute events at Londonderry House and the Royal Commonwealth Society and received its mail at the exclusive address of 55 Park Lane, London, while living herself in a modest semi-detached house in Eastbourne with her retired officer husband. Regular IAIL programmes included an atomic science short course (with film-strip projections) every first Saturday, club meetings third Wednesdays, quarterly symposia, the Ladies' Club every third Wednesday for tea and talks, and an anniversary dinner annually on 21 October at Claridge's Hotel, in addition to the publication of a quarterly digest. ${ }^{52}$ Membership fees alone were not large enough to cover these events, and Howorth's family confirms that she had no significant income and was in fact often short of funds.

In addition to lacking any independent financial means, Muriel and Humphrey Howorth had no social standing to indicate that they could themselves attract the eminent guest list featured at Howorth's atomic occasions. The description of the 1954 IAIL dinner at Claridge's sounds like a practice run for the following year's Atoms for Peace conference at Geneva, complete with atomic parlor tricks:

During pre-dinner sherry the ambassadors of many nations were shown atomic equipment by Mr. L.R. Allum, Director of Civil Defence, Ministry of Supply, who kindly demonstrated radiation equipment sent by the Ministry, including ... contamination meters with radioactive sources ... A photograph of His Excellency the Dominican Ambassador, and Dr. Myo-MookLee, Ambassador for South Korea, the Swiss Minister, M. De Torrente, and M. Gumrukcuolo from the Turkish Embassy shows their amusement when Mr. Allum detected where they had hidden uranium ore on their persons. ${ }^{53}$

49 This overlap is noted by editor Andrew Bone in the 'Introduction' to Bertrand Russell, Detente or Destruction, 1955-57, in The Collected Papers of Bertrand Russell (ed. Andrew G. Bone), vol. 29, London: Routledge, 2005, p. v.

50 Muriel Howorth's only son, Dr David Wilkinson, recorded some of his recollections of his mother in a series of 2003 letters to Sophie Forgan regarding her Atoms in Wonderland publication. These are part of the Wilkinson Collection.

51 The Wilkinson Collection contains a 'Staff records' form on which Howorth wrote a chronology of her education and employment. Along with her affiliation with the Atomic Energy Department, she recorded the acronyms RDAC and RDACI, which the author has been unable to decipher.

52 Events and locations are summarized from the announcements in Atomic Digest.

53 M. Roseby, 'International banquet', Atomic Digest (1954), p. 3. 
The account of this formal gala runs to five pages of the Atomic Digest, detailing the presence of diplomatic representatives from Burma and Afghanistan as well as the institute's standard luminary, Frederick Soddy, and Professor Otto Frisch (who was also a member of the ASA) as scientific guest of honour. Also in attendance was Mr Stanley White as the official representative of the UK Atomic Energy Authority, lately divested from the Ministry of Supply. ${ }^{54}$

The Ministry of Supply had taken over responsibility for atomic research in 1946 - the year in which Howorth received her letter - and relinquished it in 1954 to the newly formed United Kingdom Atomic Energy Authority (UKAEA). ${ }^{55}$ The dating of Isotopia to 1950 makes it clear that Howorth's Atomic Energy Association, and its Ladies Auxiliary, were an active group in these years but there are few records of their activities prior to 1953, when with 'the consent of the Ministry of Supply I gathered together many of like mind and inaugurated what has become known as the Institute of Atomic Information for the Layman'.56

With the inauguration of a new organization came a new publication, the Atomic Digest, which was one of Howorth's greatest achievements and provides the most complete documentation of her activities. An ambitious quarterly journal that ran from 1953 to 1955 , its frontispiece prominently featured the group's purpose of 'Safeguarding the Atom', emphasized by a logo of outstretched hands cradling an isotope. It was 'the only journal published solely for the layman who likes to keep abreast of the times in which he lives', and its circulation was impressive: Howorth proudly listed some fifty overseas subscribers, which ranged from the Harvard College and United Nations libraries in America to the Gosud Biblioteka in Moscow. Each volume ran to at least forty pages of professionally typeset copy, with a technical 'paper of the month', snippets of atomic news from around the world and reprints of atomic-related editorials. There were also book reviews of atomic tomes (in which works from Howorth's own New World Publications imprint figured prominently), personality pages featuring biographies of the atomic scientists, an 'Atomic Brains Trust' to whom lay readers could submit questions, and a correspondence course in atomic science devised by Donald Arnott, subsequently one of the founders of the Campaign for Nuclear Disarmament (CND) but also deeply committed to the peaceful uses of the atom. The features were often written by Howorth herself, who sometimes signed 'our lay contributor' or her husband's name on works written in a toned-down version of her own distinctive voice. In 1954 Howorth, freshly inspired by her attendance at the Nobel laureate reunion in Lindau, West Germany, was dreaming of even wider influence: proposing an international chapter of her layman's institute and launching, as part of the existing Digest, the 'Atomic World Liaison Service' to disseminate information from the more atomically advanced nations to those less fortunate. ${ }^{57}$ All of this begins to sound very much like

54 Roseby, op. cit. (53), pp. 3-8.

55 In 1946 oversight of atomic energy was transferred from the Department of Scientific and Industrial Research to the Ministry of Supply by the Atomic Energy Act. It was transferred again to the UK Atomic Energy Authority, a statutory corporation, by the Atomic Energy Act of July 1954.

56 Howorth, op. cit. (9), p. 324.

57 Muriel Howorth, 'Atomic World Liason Service', Atomic Digest (1955), p. 2. 
aspects of the recently launched American Atoms for Peace programme, a propaganda force with which she had much in common philosophically, but could not hope to challenge organizationally.

In 1955 the United States Information Service began to publish Atoms for Peace Digest, a glossy, heavily illustrated magazine which made Howorth's small-format, textbased Atomic Digest look amateurish and old-fashioned by comparison. ${ }^{58}$ Five twentyone-ton trailers rolled across Britain carrying a mobile 'Atoms for Peace' exhibition that year (Figure 3), expanding into show units nearly fifty feet long and twenty-five feet wide to accommodate an array of displays and the accompanying lectures of well-known American and British scientists, ${ }^{59}$ dwarfing Howorth's Radioactivity Jubilee, or the best of her lectures at Londonderry House. 'By agreement between our governments, we are making an extensive exchange of information concerning our discoveries and advances in atomic use', said Winthrop Browne, the US minister for economic affairs in the UK, who opened the exhibition's final run. ${ }^{60}$ Featuring pictures, models and demonstrations with which to convey the wonderful possibilities of a peaceful atomic era, the bus tour made it clear that UK-US cooperation extended to the dissemination of public information that Howorth had made her special cause. The Atoms for Peace Exhibition was attended by over 250,000 people in five months while Howorth's IAIL that year claimed just 250 members. ${ }^{61}$ These broad new PR efforts in cooperation with the US government made her own work irrelevant, and Muriel Howorth's Atomic Digest abruptly ceased publication in $1955 .{ }^{62}$ Larger forces had taken over.

\section{The Atomic Gardening Society}

In 1959 Muriel Howorth hosted another atomic occasion which would set in motion the final chapter of her unique career of atomic advocacy. With the demise of Atomic Digest in 1955 there is much less documentation of her activities, ${ }^{63}$ but four years later she was

58 Sophie Forgan points out the effect of post-war rationing on printing quality and the lack of illustration in British Cold War publications, leading to a 'reliance on old established textual representations'. Forgan, op. cit. (1), pp. 177-178.

59 Anon., 'Atoms for peace exhibition ends successful five-month British tour', Atoms for Peace Digest (1955), p. 3.

60 Anon., op. cit. (59).

61 No membership records for any of Muriel Howorth's societies have been found. This reference to 250 members is found in a newspaper article dated Saturday, 3 September 1955 in the Wilkinson Collection. The headline has been removed from the clipping, so the original source is unknown.

62 The author has found neither the exact last date of publication nor any comment from Muriel on the reasons for its conclusion.

63 The IAIL continued after 1955, at some point retitled the New Institute of Atomic Information, but the demise of Atomic Digest means that evidence of their activities is limited. There is an invitation to an 'Inaugural Dinner' in 1958 within the Howorth correspondence at the Niels Bohr archive, and a new post-1955 letterhead 'From the directorate of Atomic Information: a federation of laymen for atomic information, Ltd., Journal: Atom Review' amongst Muriel's personal papers. No record of the Atom Review has been found. Also in the personal papers is a clipping (without header or date) of a newspaper article referring to the demonstration of a laser at the fifteenth-anniversary gathering of Mrs Howorth's Institute of Atomic Information. Taking 1948 as the inaugural year, as Howorth usually did, would mean the event occurred in 1962. 


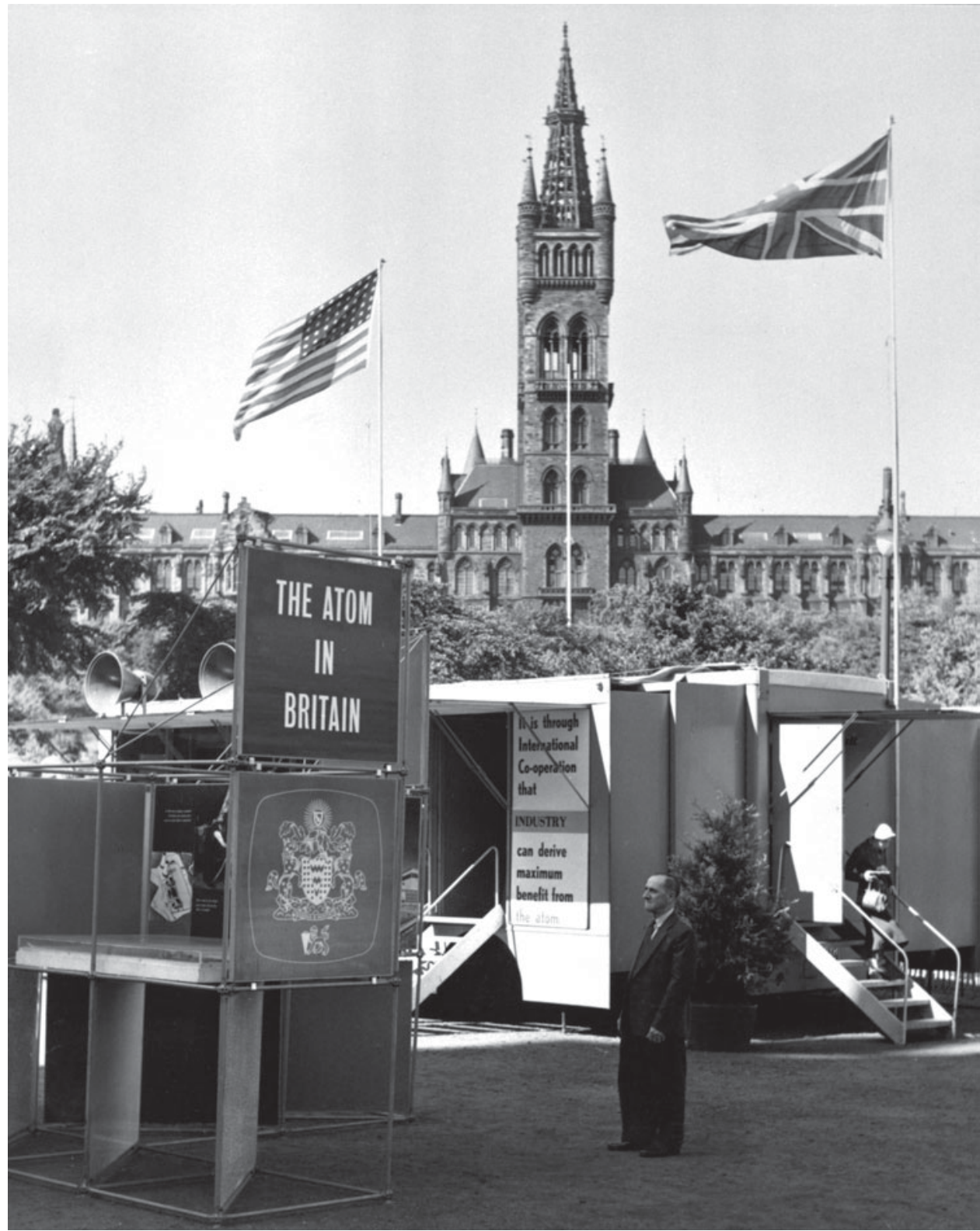

Figure 3. The Atoms for Peace bus tour visited Kelvingrove Park in Glasgow in 1955. Image courtesy of Glasgow Life/Glasgow Museums.

still able to assemble a guest list that included the American editor of Atoms for Peace Digest; a representative of the United Kingdom Atomic Energy Authority; the man who designed the first medical accelerator cyclotron, then installed at Hammersmith Hospital; and Mr K.W. Clark from the Projects Department of the Ministry of Supply. 
Howorth called these men her 'scientific friends', and they gathered along with fifty others in the dining room of the Royal Commonwealth Society for a dinner that included a strange new strain of American peanuts. ${ }^{64}$

'NC 4x', 'North Carolina 4th generation X-rayed' peanuts had been produced from seeds exposed to 18,500 roentgen units of X-rays in order to induce mutations, and they were unusually large: as big as almonds, according to those in attendance, much eclipsing the British groundnuts served alongside. They had reached the dining table through the generosity of their inventor, Walton C. Gregory of North Carolina State College, who sent them as a gift in response to one of Howorth's enthusiastic letters, complimenting him on his work in atomic agriculture. Howorth had past experience in consuming irradiated dinner fare, but her guests did not 'seem to appreciate that the nut was ... the outcome of an immense achievement'. Disappointed, in the following days she decided to 'pop an irradiated peanut in the sandy loam to see how this mutant grew'. ${ }^{65}$ The 'Muriel Howorth' peanut (she quickly named it after herself) germinated in four days and was soon two feet high (See Figure 4). She called the newspapers.

Within days there were interviews and television appearances, AP reporters in the driveway and sightseers peering into the glasshouse to get a look at the plant. Its portrait was commissioned and put on display at the Walker Galleries in London. ${ }^{66}$ Beverley Nichols, England's 'beloved gardener' and prolific garden writer, came to call:

Yesterday I held in my hands the most sensational plant in Britain.

It is the only one of its kind. Nothing of its sort has ever been seen in the country before.

To me it had all the romance of something from outer space.

It is the first 'atomic' peanut.

It is a lush, green plant and gives you a strange, almost alarming sense of thrusting power and lusty health.

It holds a glittering promise in its green leaves, the promise of victory over famine. ${ }^{67}$

'Victory over famine': it was the shorthand raison d'être of atomic agriculture, one of the three foci of the American Atoms for Peace programme. Experimentation with the effect of X-rays on plant material in the 1920s had shown that they induced inheritable changes in barley. The atomic age now enabled the application of new ionizing radiations as mutative tools, in the hope that an increased rate of random mutations would find some scramblings of the genome that made the plant a stronger, faster, more disease-resistant version of its original self.

As early as 1950, 'atomic garden' was listed as a new term in the English vocabulary, referencing the radioisotopic experiments at Argonne National Laboratories in Chicago in which plants respired in an atmosphere of radioactive carbon dioxide. These plants

64 The account of the dinner and the peanut plant is summarized from Howorth's account in Atomic Gardening. Howorth, op. cit. (5), pp. 13-17.

65 Howorth, op. cit. (5), p. 14.

66 In addition to Howorth's own account in Atomic Gardening, see Marjorie Hillary, 'So her peanut plant is filmed for TV', Eastbourne Herald Chronicle, 24 October 1959, pp. 6, 9. The portrait of the atomic peanut plant was printed on the dust cover of Atomic Gardening.

67 Howorth, op. cit. (5), p. 16. 


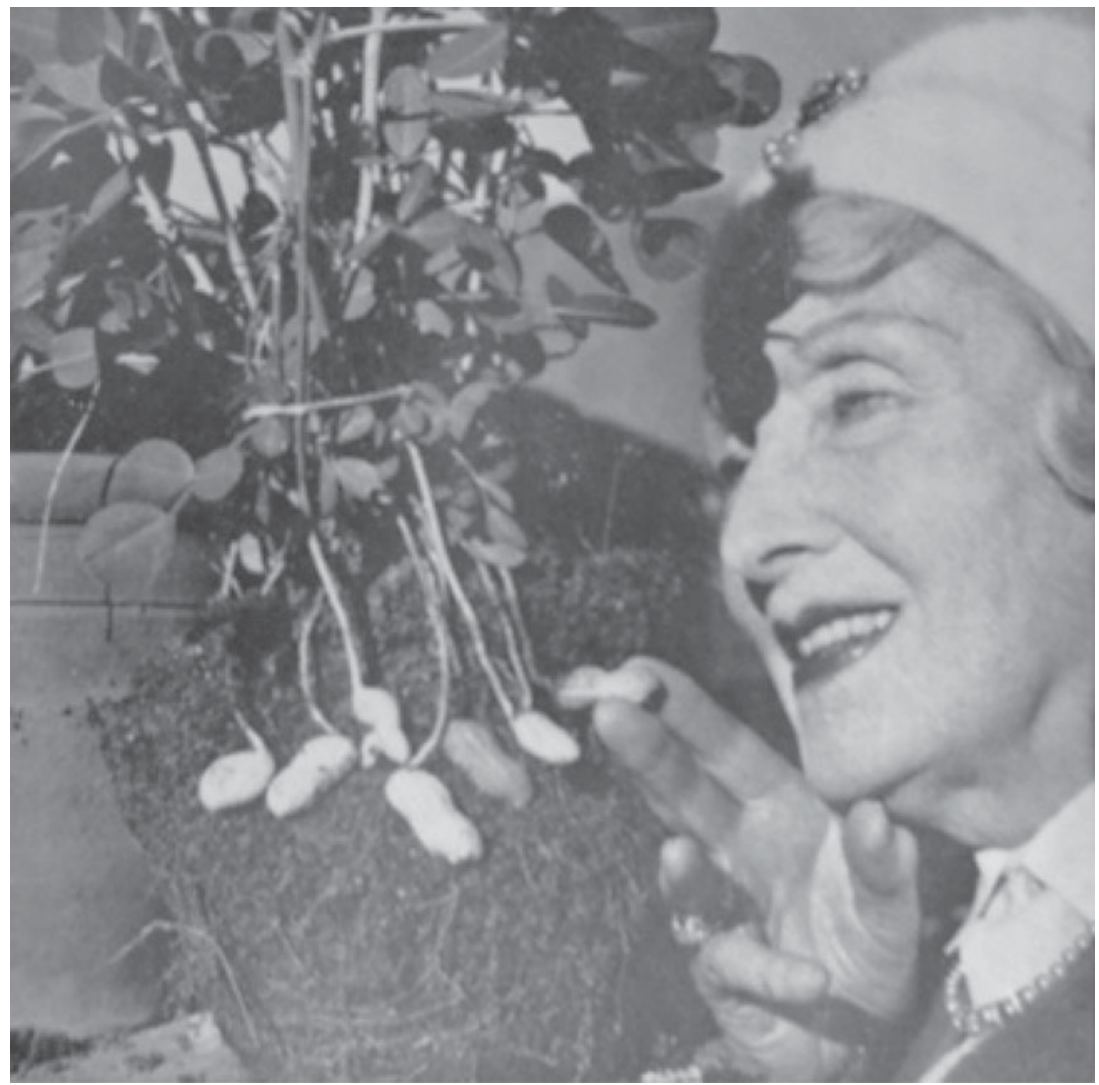

Figure 4. Muriel Howorth and her original atomic peanut plant. Reproduced from Atomic Gardening, Eastbourne: New World Publications.

became themselves radioactive, becoming both 'a tree of knowledge and a tree of life', ${ }^{68}$ acquiring the Edenic references common throughout the Atoms for Peace programme, but particularly apt for its agricultural aims. In the gamma-garden at Brookhaven National Laboratories in Rhode Island, established in 1949, plants and seeds did not become radioactive but had their genomes 'rebuilt' by being exposed to a cobalt-60 source rising totem-like from the centre of a field planted in concentric circles with plants ranging from strawberries to sugar maples. ${ }^{69}$ By 1958 atomic agriculture had been taken up in government laboratories around the world: 'gamma fields have been set up in Virginia, Florida, Wales, Sweden, Norway, Russia and Costa Rica; others are under way

68 John Algeo, Fifty Years among the New Words: A Dictionary of Neologisms, 1941-1991, Cambridge: Cambridge University Press, 1993, p. 148.

69 David Riechle, U.S. Atomic Energy Commission's Environmental Research Programs Established in the 1950s (HISAP, 1997 (cited 2011)); available from www.ornl.gov/ webworks/cpr/pres/104816.pdf. A manuscript surveying the plant irradiation experiments, including the entrepreneurial activities of C.J. Speas and a detailed account of the Atomic Gardening Society, is currently in preparation by the author. The obvious parallels to modern genetically modified crops remain to be explored. 
in Italy, India and Argentina' ${ }^{70}$ The official site for atomic agriculture research in the United Kingdom was at Wantage, where, according to a report in the popular gardening press, UKAEA scientists were carrying out experimental work on tulip and daffodil bulbs which caused them to revert to their wild states. ${ }^{71}$ Published scientific work in radiobotany from Wantage included studies of the effect of gamma irradiation on transpiration of tomato plants ${ }^{72}$ and radiation-induced sports in chrysanthemums, ${ }^{73}$ as well as experiments on seeds of flax, radish and cabbage, and young plants of flax, cabbage, lettuce, clover, duckweed and pine to establish the effect of gamma irradiation on germination and growth. ${ }^{74}$

Howorth reported seeing the resulting plants in field trials on a visit; ${ }^{75}$ she herself had been engaged in a similar research endeavour ever since she had potted up that first peanut. Going back to the modus operandi that had served her so well, and already having been served with a suitable press event by the stupendous growth of the atomic peanut, she inaugurated a new atomic society (the Atomic Gardening Society, or AGS), self-published a book (Atomic Gardening), and sought to draw influential names within the horticultural world to her cause. Most strangely, one 'Pioneer in Radiation', the so-called 'Dr' L. Ron Hubbard, founder of the church of Scientology, self-proclaimed nuclear scientist and author of All about Radiation (1957), was listed as a Scientific Advisor. ${ }^{76}$ Anyone who joined the society was offered six free irradiated peanuts, enabling them to try for the 'Muriel Howorth Peanut Prize', first prize a silver bowl, inscribed. A wider variety of seeds was soon available to members as a result of the work of Dr C.J. Speas, atomic entrepreneur, who ran the world's only private seed irradiation facility on his farm in Oak Ridge, Tennessee:

The year 1960 will be for ever memorable in the annals of atomic science... one scientific laboratory, for the first time in the history of the world, opened its doors to release irradiated food and flower seeds for lay experimentation.

The shock was staggering.

To a public...totally cut off from so much as a glimpse inside the sacrosanct atomic laboratories, the news was as incredible as if manna had fallen from heaven.

At long last the layman was part and parcel of the great atomic scheme of things. He, himself, could become an atomic plant-mutation experimenter. He might ... become a pioneer in lay experimentation for more prolific food plants for the increasing population of the world.

At least now he had the opportunity to try. ${ }^{77}$

70 Harland Manchester, 'The new age of atomic crops', Popular Mechanics (October 1958), p. 106.

71 Author, 'Notes and comments', Gardeners Chronicle, 19 January 1957, p. 58.

72 H.J.M. Bowen and P.A. Cawse, 'Some effects of gamma radiation on plant transpiration', Radiation Research (1960) 13, pp. 395-402.

73 H.J.M. Bowen, P.A. Cawse and M.J. Dick, 'The induction of sports in chrysanthemums by gamma radiation', Radiation Botany (1961) 1, pp. 297-304.

74 H.J.M. Bowen, P.A. Cawse and S.R. Smith, 'The effects of low doses of gamma radiation on plant yields', International Journal of Applied Radiation and Isotopes (1962) 13, pp. 487-492. These experiments were also referred to in the popular press: Donald Fraser, 'Radioactive gardening', Gardeners Chronicle, 31 October 1959, p. 237.

75 Howorth, op. cit. (5), p. 47.

76 Howorth, op. cit. (5), p. 65.

77 Howorth, op. cit. (5), Preface. 
Muriel Howorth's final atomic endeavour would move well beyond hosting another organization that dined and discussed. In an early example of scientific crowdsourcing, she seized upon the power of the people to come to the aid of science: 'I knew that there were, in this country, too few plant geneticists and too few laboratories. I deduced that a few thousand assistants... would greatly assist the scientists to speed up this humanitarian and scientific work. ${ }^{78}$ A plant grown from irradiated seed might change colour, be dwarfed, produce more or less fruit, remain unchanged (at least visibly) or fail to germinate at all. The nearly infinite possibilities meant that a large group of plants needed to be examined, and compared to comparable data from both fellow irradiated seeds and non-irradiated controls. Gardeners were enlisted as AGS 'mutation experimenters' and assigned blue badges. They were to keep strict data cards documenting the progress of their plants, and return them to the society. The Scientific Advisory Board of the AGS, assigned a gold badge to wear at meetings, was charged with 'assessing meritorious work, comparing useful results with those in America, and determining the value of the various growth developments in order to award certificates and prizes for merits', to be awarded in annual Atomic Plant Mutation Symposia held at the Royal Horticultural Society Hall. A list of the experimental gardens 'where atomic plants can be seen' included the Royal Horticultural Society's Garden at Wisley; the Royal Botanic Gardens, Kew; Alexandra Park, Hastings; Buxted Park gardens, Sussex; Cannell's Gardens, Norfolk; Chase (Cloche House) Gardens, Chertsey and Shepperton; Wannock Gardens, Eastbourne; and the Grange, Chertsey. ${ }^{79}$ But the official British research site at Wantage turned down Howorth's offer of assistance from her 'thousand mutation experimenters', including 'retired or non-government employed geneticists, science masters, plant breeders and pure amateurs', 80

According to a local report in Oak Ridge, by October 1960 C.J. Speas's firm had shipped 3,500,000 seeds to England, ${ }^{81}$ a prodigious number, aided by Major Howorth's acting as his 'exclusive European Agent'. ${ }^{82}$ Muriel Howorth quite naturally adopted traditional British models of garden clubs, prizes, and flower shows for her society, and an AGS stand at the Royal Horticultural Society in London in 1960 highlighted member-grown plants, including marigolds, asters, phlox, tomatoes and sweetcorn. ${ }^{83} \mathrm{Mr}$ Harold Wotton of Wannock Gardens 'set aside the old rabbit warren as an atomic garden of nine irradiated varieties of seeds with controls. THE

78 Howorth, op. cit. (5), p. 23.

79 Howorth, op. cit. (5), p. 65 . Howorth detailed the organization of the AGS, the members of the Scientific Advisory Committee and the gardens where atomic plants were located in an Appendix to Atomic Gardening. 80 Howorth, op. cit. (5), p. 47.

81 Theodore Berland, 'Atomic gardens of tomorrow-now', Oak Ridge Business and Industry (1960), p. 146.

82 Muriel Howorth may again be crediting her husband with what was in fact her own endeavour. Family memories regarding Humphrey Howorth's disdain for those involved in trade make it unlikely that he would have considered selling seeds an appropriate profession. The atom-blasted seeds were imported and distributed by Van Hage Ltd. Howorth, op. cit. (5), p. 24.

83 Marjorie Hillary, “"Atomic gardeners” take a stand at RHS Show', Eastbourne Herald Chronicle, 15 October 1960 , p. 6. 
FIRST PURELY LAY ATOMIC GARDEN IN THE WORLD' ${ }^{84}$ But though Muriel Howorth referred to progress data cards coming in 'from as far as Greece and Australia and... Switzerland, France, Germany and Holland', ${ }^{85}$ none of these have been found and the legacy of these plant trials remains unknown.

At the inception of what would be her last atomic venture, Howorth was seventy-four years of age, with failing eyesight evident in the unfocused gaze of her photographs. She soon had to relinquish her role as president, and no more is heard of the AGS past 1963. ${ }^{86}$ Neither methodology nor the loss of Howorth's charismatic leadership is to blame for its short life, however. Rather, it was that atomic gardening - like so many dreams of Atoms for Peace-never lived up to its promise. ${ }^{87}$ "The claims of overenthusiastic gardeners and seed dealers about astonishing new plants "created" by atomic radiation are doubted' ${ }^{88}$ Plantings that did not germinate at all or bore poorly would have been particularly challenging for the home gardener, and Howorth acknowledged, 'I see it is difficult for the good gardener to erase from his mind that atom treated seeds are not always going to give him spectacular results' ${ }^{89}$ Most mutative changes were undesirable, and all were unpredictable. Even the official programmes of governments, with paid personnel and dedicated procedures, produced only limited results; the US plant irradiation programme at Brookhaven, for example, was discontinued in 1979. No improved plant varieties, and certainly no victory over famine, resulted from Howorth's final nuclear enthusiasm.

\section{Conclusion}

In the same year that the Atomic Gardening Society came to a quiet end, David Lilienthal, past chairman of the United States Atomic Energy Commission and one of Howorth's atomic heroes, acknowledged that 'the glamour, the excitement, of the boundless possibilities of power from the peaceful atom is gone. The peaceful atom has not ushered in a "new world" but has rather become a part, a minor part, of the old one'. ${ }^{90}$ This was certainly true for atomic gardening; today mutation breeding techniques remain an active, though minor, area of botanical research still bearing the

84 Howorth, op. cit. (5), p. 23. The atomic garden was featured in publicity cards from Wannock Gardens, some of which remain in the personal collection of Jenny Wootton, daughter of owner Harold Wootton. She also retains a silver cup inscribed 'NC4X' which was awarded to their head gardener, Mr Mutch.

85 Howorth, op. cit. (5), p. 24.

8627 June and 10 July 1963 letters in the archives of A.M. Young at the University of Durham are written on Atomic Gardening Society letterhead listing Dr Thomas Gray as president: MSS.79/ASW/6/25.

87 For an extensive discussion of atomic dreams and disappointment in American culture relative to the Atoms for Peace programme see Paul Boyer, By the Bomb's Early Light: American Thought and Culture at the Dawn of the Atomic Age, Chapel Hill: University of North Carolina Press, 1994. No equivalent compilation exists for British nuclear culture.

88 Thomas S. Osborne, Improving Plants with Radiation, Oak Ridge: Oak Ridge Atom Industries, Inc., 1960.

89 This quote is taken from one of two undated letters from Muriel Howorth to Harold Wootton of Wannock Gardens, which are in the possession of his daughter Jenny Wootton.

90 H.L. Nieburg, 'Atoms for peace: hope deferred', Bulletin of the Atomic Scientists, January 1964, p. 35. 
title 'Atoms for Agriculture'. ${ }^{91}$ Muriel Howorth's legacy must also be acknowledged to be a minor one, her efforts notable more for their uniqueness than for their impact.

Howorth's engagement with the atomic had no contemporary peer in British culture, except perhaps on the 'other' side, amongst the impassioned women of the Campaign for Nuclear Disarmament, whose equivalent commitments would result in very different histories. Though her friend and active IAIL member Donald Arnott was among its founders, Howorth never even mentioned the CND. Or the Electrical Association for Women or the Women's Institute, who might have been natural allies. Or the celebrations of science at British museums and festivals, ${ }^{92}$ which shared many of her educative goals.

Howorth's mission to safeguard the atom was also a means of self-actualization - her passion for the inclusion of the layman a plea for her own space within the elite world of atomic science. That she was able to achieve such a space was a remarkable, but largely individual, accomplishment. The illumination she adds to a study of British nuclear culture - to the relationship between expert and lay communities, government intervention in the popularization of science, or the response of women to the atomic age - comes less from any collective action of her members than from herself. Howorth was by nature a leader, not a joiner, and allying herself with other groups would have meant giving up, or at least sharing, the credit she craved. Understanding this makes her efforts no less sincere than acknowledging that at least some of her activities were supported by government agencies. The desire to consume food altered by ionizing radiation is not easily faked, and neither is the 'ebullient enthusiasm' for all things nuclear that is Muriel Howorth's legacy. ${ }^{93}$

91 See the current state of the joint FAO/IAEA programme of the United Nations: 'Nuclear techniques in food and agriculture', at www-naweb.iaea.org/nafa/index.html.

92 Howorth certainly knew of these, and says when referring to atomic models in Atom and Eve, 'some of you will have seen them in the South Kensington Museum and other exhibitions'.

93 One of Howorth's supporters and fellow atomic gardeners, F.R. Paulsen, wrote the Introductory to Atomic Gardening, in which he said of her, 'Were she a scientist her enthusiasm and ebullience of bright ideas would surely have made her a pioneer of the Nobel Prize class.' F.R. Paulsen, Introductory, in Howorth, op. cit. (5). 